\title{
Traditions and Prospects of Remuneration of Clergymen in Czechoslovakia in the Period 1918-1950 and in the Present Slovak Republic
}

\begin{abstract}
Historical and legal examination of financial provision for the clergy from traditional and state-recognized churches and religious societies in Slovakia brings with it not only the historical dimension of its descriptive and analytical significance, but provides a specific social-security law and labour law basis for the current material status of the clergy, which is in many cases at an undignified and sociallydeprived level due to current legislation. Substantive law, even after 28 years since the political regime change in November 1989, comes from the time of real socialism, and despite a number of cosmetic changes the several times amended Act from 1949 (!) has not escaped the framework of state supervision and paternalism, as well as social levelling of Churches, at least in the case of clerical remuneration. The aim of this study was to use short, recapitulating sketches to focus historical-legal attention on the employment basis of remuneration regulation for the clergy (i.e. its basis in the form of state support called "congruence") in different constitutional phases of the Czechoslovak Republic in two diametrically-opposed political regimes: firstly the democratic $1^{\text {st }}$ Czechoslovak Republic and then the post-war People's Czechoslovak Republic, led and controlled by the Communists after their take-over in 1948. In conclusion, we analyse the current legal regulation of clerical remuneration in the Slovak Republic as one of the legal successors of the defunct Czechoslovak Federal Republic, and we describe the current major problems that we see as rooted in past legislation.
\end{abstract}

Keywords: financing of churches, remuneration of clergy, cleric (priest), congruence, churches and religious societies, minimum wage, Czechoslovak Republic, Slovak Republic

Słowa klucze: finansowanie kościołów, wynagrodzenie duchownych, duchowny, „stosowność”, kościoły i związki wyznaniowe, pensja minimalna, Republika Czechosłowacka, Republika Słowacka 


\section{Legal status and initial legislation of the Hungarian Kingdom as a starting point for the situation in Slovakia, in terms of the establishment of the first Czechoslovak Republic in 1918}

In the modern age the arrangement of the financial provision of churches and their clergy, set up during the middle Ages, has continued. This consisted in self-financing of churches and frequent support from the Sovereign as the principal patron, ${ }^{1}$ or otherwise in state subsidies and voluntary donations from the patron and local faithful. The system of self-financing was primarily bound to the use of church property (benefices ${ }^{2}$ ). These constituted an inseparable part of the landowner's property, and clergymen themselves were landowners in the sense that their office as well as the related benefice (incumbencies) were taken from them as a fief. ${ }^{3}$ By virtue of the mutual patronage relationship, ${ }^{4}$ landowners were usually also patrons of that benefice, ${ }^{5}$ but from medieval times until the late $17^{\text {th }}$ century, the patron did not bear any compulsory financial burden, and even the bearing of it could not be coerced ${ }^{6}$. Change came only at the turn of the $17^{\text {th }}$ to $18^{\text {th }}$ century ${ }^{7}$. It was caused by the need to improve the material conditions of the Catholic Church $^{8}$ and consisted in the order for patrons to care for the needs of the churches acting within their tenure. Regulations that were issued in the former Hungarian Kingdom however were focused mainly on the enforcement of patronage obligations, not for permanent material support of the clergy. Otherwise clergymen had to rely on income from the ecclesiastical benefice, direct financial or material support from the relevant patron, possibly on vestment fees (taxes) and voluntary donations from the faithful, and in the case of the reformed churches and religious communities (e.g. Jewish) on their own communal financial provision.

1 For example, legal articles LXXIV/1715 and LXX/1723 confirmed the highest patronage right of Hungarian rulers to all religious endowments, endowment of church schools, seminaries and colleges.

2 Benefice (incumbencies) is an expression of Canon Law and represents income or assets associated with a particular priestly ministry, position or authority, or even this position itself. Incumbencies were created already in the early Middle Ages, from the proceeds of land ownership of the church and were the only way in medieval economy permanently ensuring the livelihood of local priests or vicars. See The Hungarian legal dictionary, A. Bartal, Glossarium mediae et infimae latinitatis regni Hungariae, Lipsiae-Budapestini, 1901, p. 73.

3 Cf. J. Munka, Patronátne bremená a cirkevné dávky, Dunajská Streda 1937, p. 5-6.

4 Patronage consisted of rights granted by the Church, and of obligations imposed by the patron based on the granted rights, which the clergy were obliged to bear. Ibidem, p. 5, 11 .

5 Patronage rights were in fact a complex of rights and duties which patrons had to fulfil and use. Voluntary compliance 'duties' of patrons included the supervision over the beneficiary, subsidies for the parish priest and reimbursement of major repairs of church buildings, churches or chapels. The principal personal patron was the Hungarian king or state and in addition to him patrons could be church funds, free royal towns, municipalities or private individuals.

6 Cf. ibidem, p. 14.

7 Cf. J. Munka, Patronátne bremená..., p. 15 et seq.

8 The Catholic Church at the time of Turkish dominion in Hungary, as well as at the time of the Reformation, suffered considerable damage to its property, which was either completely destroyed or confiscated by the Turks. 
Pay for performance of the priesthood became the subject of regulation only after the state-recognized or registered churches (hereinafter "the churches"), or rather their clergymen, got into unbearable material deprivation, and the state undertook to subsidize their material (financial) provision. This subsidizing activity appeared only in the time of enlightened absolutism in the late $18^{\text {th }}$ century. It was intended, among other things, as an attempt to resolve the adverse social and financial situation of the priesthood by means of a special state contribution (or income supplement) called congruence, which complemented the other income of the clergy up to the level of at least the subsistence minimum appropriate to their social status. ${ }^{9}$ The foundations of the congrual system were laid by Joseph II, who established a religious fund. ${ }^{10}$ This religious fund took over the obligation to ensure congruence, but this obligation was applicable only to newlyestablished rectories. As the income from churches' own assets were nevertheless insufficient to cover the dignified and adequate material provision of the clergy, during the $19^{\text {th }}$ century proposals were made for new rules for the remuneration of clerics, or rather the above-mentioned congruence, but due to the unwillingness of government and also the financial problems of the state, the first congrual laws were adopted in the Hungarian Kingdom in the 1890s. A model for solutions to the clergy's unfavourable material situation was also sought in the Austrian part of the empire, where the situation was partially resolved through the adoption of Act no. 51/1874 Coll. on contributions to the religious fund. The first congrual legislation was Act no. 47/1885 Coll., which among other things granted in principle to all independent rectors and their clerical subordinates entitlement to supplementary congruence from the religious fund. ${ }^{11}$ This so-called provisional congrual act was repealed by Act no. 176/1898 Coll., which remained in force in the western part of the empire until the collapse of Austria-Hungary in 1918. In 1902 an official salary for rectors was introduced, and congruence was later increased several times. ${ }^{12}$ The congrual acts committed the State to supplementing the welfare of those priests in the

9 Congruence (portio congruae) is the canonical-law term referring to the subsistence minimum which is provided to clerics appointed to a given place in the church administration. In confessional law Congruence is used as a term for the supplement which is provided from public funds to remedy inadequate congruence from the church (salary of the cleric provided from church sources). See J.R. Tretera, Stát a cirkve v České republice, Kostelní Vydří 2002, p. 32 and M. Šabo, Štát a cirkvi na Slovensku. Vývoj financovania cirkví, Bratislava 2006, p. 38.

10 In: Slovník veřejného práva československého. Svazek II., eds. E. Hácha, J. Hoetzel, F. Weyr, K. Laštovka, Brno 1932, p. 293. The Religious Fund (fundus religionis), the so-called religious matrix, was established during the reign of Joseph II from a levy on the property of mendicant monasteries and contemplative orders. Because the clerics were regarded as civil servants and the church as a state institution, management of the Fund's assets was taken over by the state, which simultaneously undertook to complement those assets as needed from the state property. It was mainly intended for the completion of the parish network, so newly-created parishes were financed from it, and thus it could be used for the material support of clerics. For details of their social security in the Enlightenment period, esp. in Josephine times see I. Kušnyráková, Piae fundationes. Zbožné fundácie a ich význam pre rozvoj uhorskej spoločnosti v ranom novoveku, Bratislava 2009, s. 20-23, 161-162.

11 For details of developments in the Austrian part of the empire before the establishment of the first Czechoslovak Republic, see the headword "kongrua" (congruence) [in:] Slovník veřejného práva..., p. 292-293.

12 Cf. K. Malý, F. Sivák, Dejiny štátu a práva v Československu do roku 1918, Bratislava 1992, p. 290. 
Catholic Church administration whose incomes were not adequately covered from the main church revenues, revenues from benefices and vestment revenues from believers. ${ }^{13}$

The Hungarian Kingdom acceded later to similar solutions by introducing congruence payments, which was a consequence of the abovementioned different relationships between the Church and the state. Due to the fact that the property of the Catholic Church in Hungary allowed the provision of support to the poor clergy from its own resources, the first adjustment of congruence in statutory article XIV/1898 related only to other congrual churches,${ }^{14}$ admitted by statutory article XLII/1895, and not to the Catholic Church. No change occurred until statutory article XIII/1909, when congruence was granted to the clergy of the Catholic Church, but only under the condition that the Catholic Church would also contribute for this purpose from its endowment. ${ }^{15}$

\section{The remuneration of clerics in Czechoslovakia during the period $1918-1950$}

\subsection{Legal basis in the first Czechoslovak Republic}

The income of the clergy still consisted of proceeds from benefices, congrual contribution and state contributions, vestment taxes and voluntary contributions (donations) of believers. By means of these state contributions and congruence the state thus contributed to the financial provision of churches, and for the holders of small benefices in particular congruence became an essential part of their material provision. The above-mentioned legislation continued from the time of the dualistic Austro-Hungarian Empire, but for resolving the legal dualism and social and employment disproportion between the western (Czech, Moravian and Silesian) and eastern (Slovakia and Carpathian Ruthenia) parts of the country ${ }^{16}$ as early as 1920 resolutions of the Czechoslovak parliament were adopted, which granted allowances to congrual Churches (with the exception of Jewish communities) for "wage improvement" and emergency spending and shopping supplements up to several hundred crowns a year. This briefly-outlined material and social provision of

13 J.R. Tretera, Stát a cirkve..., p. 32.

14 Those churches under the then legislation were the Lutheran Church (Augsburg Confession), the Calvinist (Reformed) Church, the Eastern Churches (Serbian and Romanian, i.e. Russian Orthodox), the Greek Catholic (Unitarian) Church and the Jewish religious community.

15 The amount of congruence under initial Hungarian legislation was $1600 \mathrm{~K}$ for an independent cleric, $1000 \mathrm{~K}$ for a junior cleric, and $800 \mathrm{~K}$ for a cleric with incomplete qualification. In addition, statutory article XXXVIII/1913 also added some supplements according to age, and statutory article XXXV/1912 introduced a so-called family supplement of $400 \mathrm{~K}$ for each child living in the cleric's household and having no other income. Cited by Slovník veřejného práva..., p. 294-295.

16 At this point it should be noted that the remuneration of clerics had its centuries-old tradition in both parts of the newly established republic by completely different legal, custom or legal provisions, it passed surely its difficult periods and especially in both parts of the republic were also different economic and business conditions of inhabitants of individual two parts of the republic. Ensuring of the clerics therefore were differed from parish to parish and it is almost impossible to express which legal order during the existing legal dualism was the clerics preferable. 
the clergy, standardized even in terms of Austro-Hungarian dualism, can be described as a rather complicated and opaque system of financing, which lasted until $1^{\text {st }}$ January 1926. The new system of payment of congruence, which incidentally annulled the earlier payment of benefits and contributions, was governed by the generally-applicable Act no. 122/1926 Collection of laws and orders on the adjustment of salaries of the clergy of churches and religious communities recognized or admitted by the State (hereinafter "the Congrual Act"). With the Congrual Act the Czechoslovak Republic enjoyed a unified legal definition. Its implementing provisions became the Government regulation no. 124/1928 Collection of laws and orders on the salary adjustment of the clergy. The Act primarily followed up on the previous regulation, the differing congrual legislation in the Czech Republic and Slovakia, and made arrangements for granting contributions in a more permanent way. ${ }^{17}$ The regulation of previous congrual acts that were not in contradiction with it left the Congrual Act no. 122/1926 Coll. still in effect. ${ }^{18}$

Compared to the previous regulation, however, it brought some substantial changes that reflected the significant socialization changes of the First Republic expressed in labour and social legislation. ${ }^{19}$ The most essential was the introduction of the concept of salaries of clerics, which was composed mainly of congruence and educational allowances for children. The Act set the basic criterion for entitlement to congruence payments, which was to meet the following requirements: Czechoslovak citizenship, graduation from university, and proven physical fitness to perform office within the church administration ( $\$ 1 \mathrm{sec} .4$ of the Congrual Act and $\S 3$ of the implementing regulation). Clerics of the so-called "congrual churches" had legal right to the congruence supplements, i.e. Roman Catholic, Greek Catholic and the Orthodox Church throughout the territory of Czechoslovakia, and in the case of Slovakia also the Lutheran Church, the Calvinist (Reformed) Church and Jewish communities. ${ }^{20}$ Other churches were called subsidiary and only received a lump sum of state subsidy for the salaries of their clergy. ${ }^{21}$ One of the reasons for the emergence of a new Congrual Act was the effects of the first land reform, which significantly reduced the land fund (i.e. the basis of ecclesiastical benefices) of the Catholic Church. Czechoslovakia started providing compensation for the loss of land property in Church ownership gradually from as early as 1920 by increasing congrual supplements to the income of the clergy, provided through religious funds.

The Congrual Act and its implementing regulation established the lowest income (congruence) of clergy active in the administration of parish offices, as well as in other public religious administration. Congruence was determined as an annual amount

17 Cf. M. Šabo, Štát a cirkvi..., p. 48.

18 On the issue of congruence legislation in the first Czechoslovak Republic see also J.R. Tretera, Z. Horák, Konfesni právo, Praha 2016; and V. Valeš, Právni úprava postaveni církvi a náboženských společností v obdobi prvni Československé republiky (1918-1938), Praha 2013.

19 For an overview see M. Laclaviková, Formovanie pracovného práva a práva sociálneho zabezpečenia na našom území začiatkom 20. storočia [in:] Právnohistorická realita sociálnej doktríny 20. storočia, Kraków 2013, p. 63-115.

20 See $\S 1$ of the implementing regulation no. 124/1928 Coll.

21 The state subsidy was specified in $\S 5$. These were the other churches, namely the Czech Brotherhood Church, the Czechoslovakian Church, the Old Catholic Church, and the Jewish religious community in the territory of Bohemia, Moravia and Silesia. 
increased every three years of service (so-called "triennnials"), but not more than ten times. ${ }^{22}$ Congruence complemented clergymen's net income assessed on the basis of financial declaration (so-called "fassie"). On the other hand, congruence was reduced by other income from public funds (except for fares, remuneration for the teaching of religion in schools, or parliamentary salary). The income also included revenues from the parish property, real estate, interest revenues, trade licensing income, income from commercial rights, and vestment fees. Counted income was always set for five years in advance (so-called "lustrum") by averaged "fassie" over the last three years preceding the lustrum. ${ }^{23}$ In the case that clergymen were taking care of dependent children, they were also entitled to an educational allowance, while widows and orphans after the clergyman were entitled to the widow's or the orphan's pension. Furthermore, according to second part of the implementing regulation they were also entitled to old-age social security (so-called rest and provident salaries) and other benefits.

Also after the creation of the Slovak State (1939-1945), the Tiso regime undertook to continue the payment of congruence under the Act from 1926, which was tied to the acquisition of Slovak citizenship or swearing of the civil oath. The end of World War II may have brought with it continuity of the original legislation, namely the First Republic Congrual Act, but now there was emphasis on proper denazification and defascification of the priesthood. Priests who were prosecuted as traitors, collaborators, Germans and Hungarians, in short, those who had experienced Czechoslovak statehood and had been in favour of the pro-fascist regimes both in the Czech Republic and Slovakia during the war, no longer had any legal claim for congruence.

\subsection{Legal basis of the People's Czechoslovakia}

Following the Communists accession to power in February 1948, the legal situation changed radically and immediately and in many ways, although state support and hence the congrual legislation did not disappear. The real intention of the Communists in religious matters was also soon manifested: to disrupt the unity of the Church and deprive it of its independence from the state in the economic sphere. The core of changes in the economic area consisted in Act no. 217/1949 Coll. on state supervision over the churches, and the Government regulation no. 219/1949 Coll. on the financial provision of the Roman Catholic Church by the state. These legal actions clearly involved violation of citizens' fundamental freedoms, including the freedom of religion guaranteed by the Constitution.

The new basis of church funding emerged in new congrual legislation in the form of Act no. 218/1949 Coll. on the financial provision of churches and religious communities by the state (hereinafter "the 1949 Act") (supplemented with a series of imple-

22 Cf. $\S 1$ of the Congrual Act: "The lowest income (congruence) of clerics of state-recognized or prescribed congrual churches and religious communities, active in the administration of parish office and in other public church administration in systematized locations with the consent of the state religious administration, is determined as an annual amount of 9.000 ,- Kč, which is increased after every three-year period of service with an increment of $972,-$ Kč, not exceeding a total of ten times".

23 Cf. $\S 3$ of the Congrual Act.

Artykuły - Articles 
menting regulations which determined the specific amounts of basic salary, the method and the rate of increase, the conditions for granting seniority allowance and the amount thereof, as well as the conditions for granting rewards for higher performance and details of this remuneration ${ }^{24}$ ). According to the new legislation the state took over full responsibility for the remuneration of clerics, who were paid wages directly by the state as socalled personal benefits ${ }^{25}$ (i.e. no longer congrual contributions) only when they worked in church management, church administration, or in an institution for education of the clergy, but essentially with state consent ${ }^{26}$ and after taking the oath of allegiance to the Republic ( $\S 7$ of the 1949 Act; for the wording of the oath see $\S 19$ of the implementing regulation). That was one of the most important legal conditions for the granting of the salary. ${ }^{27}$ On the basis of $\S 1$ of the implementing regulation, this resulted in one substantial legal conclusion that clergymen became full government employees, even though they formally remained in employment with their church governing authorities, their employer became their local District People's Committee (ONV) and particularly the State Office for Church Affairs. In this way a curious bipolar employment relationship was created to the state and also the domestic church, while the direct financial/economic dependence of the clergy on the state was deepened. Even though the state presented the new arrangements as a kind of compensation for confiscated church property, ${ }^{28}$ it was mainly a simple and effective means of control over the activities of churches and religious communities. Churches ceased to have the character of public bodies and in financial matters they became, and along with them the clergy, totally dependent on the state. ${ }^{29}$

The 1949 Act also set up a new salary scheme for the clergy, and while the basic salary of clerics before the currency reform in 1953 was 3000,- Kčs a month, after the revaluation it was 600 ,- Kčs, which on the one hand was advantageous for the clerics

24 These were Regulation no. 219/1949 Coll. on the financial provision of the Roman Catholic Church by the state, Regulation no. 220/1949 Coll. on the financial provision of the Czechoslovak Church by the state, Regulation no. 221/1949 Coll. on the financial provision of the Protestant Churches by the state, Regulation no. 222/1949 Coll. on the financial provision of the Orthodox Church by the state, Regulation no. $223 / 1949$ Coll. on the financial provision of religious communities by the state. This set of listed legislation in the later period was supplemented with Regulation no. 70/1968 Coll. on the financial provision of the Greek Catholic Church by the state.

25 Personal benefits of clerics consist of the basic salary, the rank allowance and bonuses for better performance. Clerics who were entitled to personal benefits should also be entitled to reimbursement of travel, moving and other expenses under the general rules.

26 State consent could be granted only to clerics who were Czechoslovak citizens, were reliable for the state and irreproachable and otherwise complied with the general conditions for admission to the civil service. The State Office for Church Affairs could waive the condition of citizenship in cases deserving special consideration.

27 Swearing of allegiance was an effective means of putting pressure on priests. Cf. J. Pešek, M. Barnovský, Štátna moc a cirkvi na Slovensku 1948-1953, Bratislava 1997, p. 99-100.

28 Mostly on the basis of Act no. 142/1947 Coll. on the revision of the first land reform, Act no. 46/1948 Coll. on the so-called new land reform, but also on the basis of the other legislation, for example Act no. $85 / 1948$ Coll. on the nationalization of medical and nursing institutions and the institutional organisation of state medical care, Act no. 169/1949 Coll. on military districts, Act no. 95/1948 Coll., on basic provisions for uniform education (the Education Act), Act no. 125/1948 Coll. on the nationalization of natural resources and medicinal spas and integration and management confiscated spa property, Act no. 124/1948 Coll. on the nationalization of some inn holder and taproom businesses and accommodation facilities.

29 Cf. M. Moravčíková, Štát a cirkev v Slovenskej republike [in:] Štát a cirkev v postsocialistickej Európe, ed. S. Jozefčiaková, Bratislava 2003, p. 101. 
from the financial point of view compared with the previously-existing congruence and other state contributions, but on the other hand it clearly predicated social levelling and moral degradation of most of the clergy in the Communist people's Czechoslovakia. ${ }^{30}$ The salary was increased only marginally by $300,-$ Kčs after three years. In addition to the basic salary, there were four categories of personal rank supplements for church offices from the parish priest to the bishop..$^{31}$ This salary was not granted to clerics who were being prosecuted or who had been convicted; those whom the bishop appointed to office after the 1949 Act was passed, but without applying for state consent, or who were opposed to the so-called Catholic Action. ${ }^{32}$ By means of this procedure and the new salary policy the Communist regime bound all loyal clerics. At the same time it was interested in controlling the widest possible range of persons concerned, as well as giving the state the highest level of supervision over the property of all recognized churches, closing the ring of material dependence on the state and bringing all recognized churches under direct, close supervision by the state or rather by Party ideology. It also erased the direct employment relationship between clerics and their local superior, or members of the local church or religious society.

Addendum: Only with the change in social relations after November 1989 was there a change in the remuneration of clerics in the sense that the State began provide subsidies for the salaries of clerics and partially material expenses directly to the head offices of the individual churches and religious communities, or to dioceses. ${ }^{33}$ Thus subsidies for clerics' remuneration still remained in some way a continuation of congruence and a temporary replacement for restituted religious property.

\section{Clerical remuneration in present-day Slovakia as a direct historical and legal legacy}

The current Slovak Republic is not constitutionally linked to any ideology or religion, but it provides its citizens very good conditions for spreading both freedom of religion and religious freedom. ${ }^{34}$ For this purpose, the state provides registered churches and religious communities support in exercising their religious and charitable activities, guaranteeing their legal status and the possibility of acting in public life. ${ }^{35}$ At the same time it grants the registered churches and religious communities, if requested, funds to cover the personal benefits of clerics in church management, church administration or in institu-

\footnotetext{
30 M. Šabo, Model financovania Katolickej cirkvi v Slovenskej republike v kontexte vývoja, princípov a perspektív vztahov štátu a cirkvi vo svete, Bratislava 2008, p. 160.

${ }_{31}$ V. Vaško, Neumlčená. Kronika katolické cirkve v Československu po druhé světové válce, Praha 1996, p. 105.

32 J. Pešek, M. Barnovský, Štátna moc ..., p. 113.

33 Cf. Regulation no. 578/1990 Coll. on the adjustment of personal emoluments provided for clerics of churches and religious communities

${ }^{34}$ Cf. L. Tóth, Postavenie zamestnancov cirkví..., p. 1.

${ }_{35}$ M. Moravčíková, M. Cipár, Cisárovo cisárovi. Ekonomické zabezpečenie cirkví a náboženských spoločností, Bratislava 2001, p. 75.
} 
tions for education of the clergy. As we have already mentioned, the basis of the current legislation regulating the remuneration of clerics represents the still valid, although several times amended, Act no. 218/1949 Coll. on the financial provision of churches and religious societies, as amended. ${ }^{36}$

The current model of financing of churches and religious communities does not reflect the existence of an employment relationship between the churches and religious communities, which act as employers, and the clergyman as an employed person, with the result that the provision of subsidies ultimately overshadows the fact that churches and religious communities are obliged to provide clerics remuneration in line with labour law regulations. Under the 1949 Act clerics are provided remuneration by their employer, i.e. the relevant church or religious community, ${ }^{37}$ but funding for the salaries of clerics and insurance contributions is however provided by the state in the form of direct subsidies within the approved state budget. ${ }^{38}$ Under the Constitution the number of clerics and the entire personnel policy is determined solely by each church or religious community itself. ${ }^{39}$ Although the state has a legal obligation to ensure salaries and insurance contributions for all clerics, this has no effect on their number. ${ }^{40}$

If we look at one specific subsidy, the state provides churches and religious societies reimbursement of personal emoluments of clerics acting as employees of a particular church or religious community in church management, church administration, or in institutions for education of the clergy, and if the church or religious community requests, also further reimbursement of travel, moving and other expenses, proper material costs associated with the performance of religious services and other religious acts with the church administration, and special assistance with extraordinary material costs. Personal emoluments according to the 1949 Act are considered to be the basic salary, rank sup-

36 The nature and philosophy of the still valid Act no. 218/1949 Coll. originated moreover in the diametrically different political and historical situation of the Communist regime, and today its application as well as its basic principles are already unsatisfactory.

37 Persons performing clerical activities carry them out through delegation by churches and religious communities according to their internal rules and generally applicable legislation. Although persons who have chosen clerical or monastic life perform their profession without a standard employment contract, without remuneration and with their profession understood as a mission and service to God and to the Church, in the performance of their work they necessarily end up in a legal relationship with their church or religious community, whereby this relationship has many features of an employment contract, and the relevant church or religious community has the status of employer. On this issue see also V. Žofčinová, R. Gyuri, Osobitosti v pracovnoprávnom postavení zamestnancov cirkvi a náboženských spoločností [in:] Sloboda jednotlivca a svet práce, eds. V. Križan, M. Moravčíková, Praha 2014, p. 120; L. Tóth, Postavenie zamestnancov cirkví a náboženských spoločností [in:] Teoretické úvahy..., p. 250-251; I.A. Hrdina, Pracovněprávní poměry duchovních a Zákonník práce, "Právník" 2007, iss. 8, p. 940; and H. Barancová, Slovenské a európske pracovné právo, Žilina 2004, p. 91.

38 The National Council of the Slovak Republic annually approves the state budget, in which certain financial expenditures are intended for churches and religious communities, and the administrator of finances is the Ministry for Culture of the Slovak Republic, specifically its Cultural Department, which allocates funds to churches and religious communities according to their budget ( $\$ 9$ of Act no. 218/1949 Coll.).

39 R. Cikeš, Financovanie cirkví a náboženských spoločností štátom [in:] Clara pacta - boni amici. Zmluvné vzt’ahy medzi štátom a cirkvami, eds. M. Šmid, M. Moravčíková, Bratislava 2009, p. 67.

40 In addition to financing the salaries of clerics, the state for the most part covers the operation of church headquarters (bishops' offices) through direct subsidies. Yearly contributions provided to churches and religious communities have to be accounted for, and they must procure other necessary funds from their own resources. See M. Moravčíková, M. Cipár, Cisárovo cisárovi..., pp. 75-76. 
plement and increase in the basic salary in appreciation of high-quality performance of liturgical activities. The amount of the basic salary, the conditions for granting the rank supplement and its amount, and conditions for granting an increase in salary in appreciation of the high quality of performance of liturgical activities and details on this increase are stipulated in the regulation of the Slovak Government no. 299/2007 Coll. on the treatment of personal emoluments provided for clergymen of churches and religious communities, as amended.

The basic salary of particular clerics is determined by the classification of the functions performed into the corresponding group ${ }^{41}$ and the period of performance of eligible activities in the church administration (Annex no. 1 of the government regulation) ${ }^{42}$ The rank supplement is provided by the inclusion of the cleric's office in group $\mathrm{C}$ up to $\mathrm{G}$ commensurate to the responsibility and the importance of the office performed within the clerical activities listed in $\S 9$ of the 2007 Act. The implementing government regulation lays down only the range of the amount of supplement, whereas its specific amount is determined by the appropriate church. ${ }^{43}$ The church can increase the basic salary for clerics set for the corresponding salary grade by up to $30 \%$ of their basic salary in appreciation of their high quality of clerical activities. ${ }^{44}$

From a labour law perspective it should be emphasized that the remuneration in labour relations belongs in the so-called property-law content part of the employment contract, in which the churches and religious communities should proceed as any other employer. However, as seen from the highly-problematic legal practice, the working relationship between the relevant church and clergymen remains unrecognized in both legal and social respects. We can therefore assume that the 2007 Act in connection with the government regulation governs only the amount of the subsidy granted by the State for the payment of remuneration of clerics, not remuneration which churches and religious societies should provide to clerics who are in the position of employees of church or religious society. Remuneration should therefore come under the general provisions of the lex generalis Act no. 311/2001 Coll., i.e. the Labour Code as amended. Its provision of $\S 3$, section 3 establishes the subsidiary scope of the Labour Code in employment contracts of persons performing religious activities. The labour-law status of employees of churches and religious communities who perform religious activities is governed by the Labour Code, unless stipulated otherwise by the Labour Code itself, or by special regulation, any international treaty by which the Slovak Republic is bound, any treaty concluded between the Slovak Republic and churches and religious communities, or the internal regulations of churches and religious communities. This view is confirmed by the judgement of the Constitutional Court of the Czech Republic, ${ }^{45}$ according to which in

${ }^{41}$ Annex no. 2 of the government regulation contains groups of offices of clerics.

42 See Annex no. 1 of this contribution.

43 The rank supplement for clerics who carry out the office included in group:

a) $\mathrm{C}$, is from 6,64 to 23,24 euro a month,

b) $\mathrm{D}$, is from 16,60 to 39,84 euro a month,

c) E, is from 26,56 to 66,39 euro a month,

d) $\mathrm{F}$, is from 43,16 to 99,59 euro a month,

e) $\mathrm{G}$, is from 66,39 to 165,97 euro a month.

44 See $\$ 3$ of the Government regulation.

45 Finding of the Constitutional Court of the Czech Republic I. ÚS 211/96 from $26^{\text {th }}$ March 1997. 
the case of remuneration and wage compensation or other property claims by employees, there is no interference with the internal autonomy of churches and their decision making. For these or similar property claims the private law nature of the Church as a legal entity stands out, which entails certain obligations for legal entities or natural persons (and thus for clergymen) and these persons should have equal labour law status before the law.

For the most populous church in Slovakia, the Roman Catholic Church, the internal rule governing the relations between the clerics and the Church is the Code of Canon Law (hereinafter "the CIC") However, the CIC provides for clerics' remuneration only in very general terms According to canon 281 of the CIC, clerics "deserve remuneration which is consistent with their condition, taking into account the nature of their office and the conditions of places and times, and with which they can provide for the necessities of their life as well as for the equitable payment of those whose services they require". The remuneration of married deacons is established separately.

The Labour Code does not set any upper limits for salaries provided, although the contractual freedom of the parties to the employment relationship is limited by the statutory minimum wage. ${ }^{46}$ Under $\$ 134 \mathrm{sec} .5$ of the Labour Code, the average pay of any employee must not be lower than the minimum wage; if the identified or applied average earnings of an employee are less than the amount guaranteed by law, the employer is obliged to increase those earnings to a sum corresponding to this minimum wage. Pursuant to the provision of $\S 119 \mathrm{sec} .1$ of the Labour Code, wages cannot be lower than the minimum wage determined by special regulation. This provision refers to Act no. $663 / 2007$ Coll. on the minimum wage as amended. ${ }^{47}$

As mentioned above, the current model of financing of churches and religious communities does not reflect the existence of an employment relationship between the churches and religious communities, which act as employers, and the clergyman as an employed person. Moreover the basic salary of clerics, according to the implementing regulation of the Government, does not satisfy in all cases the right to a minimum wage, and in some cases even the minimum wage itself. As employers under the Labour Code, churches and religious communities are obliged in addition to the remuneration provided under the government regulation also to provide their clerics a supplement to the amount of the minimum wage, which however (and despite the statutory requirement to provide compensation equal to their position in the CIC) does not happen at present. This is therefore a violation of labour legislation. Further problems occur even in the application of remuneration of clerics. Under $\$ 52 \mathrm{a}$ of the Labour Code, the provisions on working time do not apply to labour-law relations of employees of churches and religious communities who perform religious activity. And so although it is not possible to apply the provision $\S 96$ of the Labour Code, which regulates overtime, employers are bound by the provision of $\S 121$ of the Labour Code, under which they are obliged to provide their employees overtime pay in addition to their salary. Extra pay for overtime, for work on

46 H. Barancová, R. Schronk, Pracovné právo, Bratislava 2013, p. 366.

47 For the year 2017 legislation established the minimum wage valid from $1^{\text {st }}$ January 2017 as 435 ,- euro for an employee paid a monthly wage, or 2.50 euro for each hour worked by the employee. 
public holidays and night work, is not taken into account even by government regulation. ${ }^{48}$

In addition to the above, the current remuneration regulation of clerics represented by the government regulation does not take into account the personal status of clergymen. The income of a clergyman living in celibacy is the same as the income of a priest who may be, or rather is a family breadwinner. Such a low income for a clergyman who is a family breadwinner puts his family in an unfavourable financial situation, which often must resolve by means of a second, civilian employment.

\section{Conclusion}

It is apparent from the presented historical excursion that the model of clerical remuneration existing in the Slovakia is traditional and has historical roots in the first Hungarian congrual law-making of the late $19^{\text {th }}$ century. If we evaluate the outlined historical and legal context of this socially "hot" topic of remuneration, which is also strongly perceived by the lay and atheistic public, the most important conclusion which we reach in our contribution is the unfortunate finding that the current regulation of remuneration of clerics is insufficient, because in the forefront is the relationship state - church, while the employment relationship church - cleric, which clearly involves the cleric's remuneration as an employee, remains in the background. As a result, the situation arises where clerics' remuneration not only fails to satisfy the requirement of the right to a minimum wage, but in some cases also the provision of the minimum wage itself. From this perspective of direct state subsidy, which was and remains historically established even from the time of the Enlightenment supervision over church property (especially the most populous Catholic Church), the present-day financial provision resulting from the remuneration of clerics described above, produces in many cases an undignified and socially-deprived level of material status of clerics in Slovakia. In addition the current (as well as the previous) legislation in substantive law still comes from the times of real Socialism even 26 years after the regime change in November 1989, and despite a number of cosmetic changes several legal amendments have not exceeded the scope of state supervision and paternalism, as well as social levelling of churches and religious companies and their clergy. Although a church or religious community is obliged as an employer to supplement clerics' remuneration up to the minimum wage, given the resources which the church or religious community has available, this does not happen. In practical application therefore there not infrequently occur cases where the income of a cleric is insufficient to cover his living needs, or living needs of his family. The solution is in many cases a second, civilian employment. Since taking into account the historical context it is possible to attribute responsibility for this situation to the state, the state should, in close cooperation with churches and religious communities, actively resolve this situation.

48 Cf. A. Olšovská, Pracovnoprávne postavenie osôb vykonávajúcich duchovenskú činnost', “Acta Universitatis Tyrnaviensis", Trnava 2005, p. 263. 
Annex 1. The scale of basic salaries of clerics in euro per month under the current legislation (Annex no. 1 to Government regulation no. 299/2007 Coll.)

\begin{tabular}{|c|c|c|c|c|c|c|c|c|}
\hline \multirow{3}{*}{$\begin{array}{l}\text { Salary } \\
\text { grade }\end{array}$} & \multirow{3}{*}{$\begin{array}{c}\text { Counted period of } \\
\text { carrying out clerical } \\
\text { activity in years }\end{array}$} & \multicolumn{7}{|c|}{$\begin{array}{l}\text { The scale of basic salaries by group assignments and the counted period } \\
\text { of performing clerical activities }\end{array}$} \\
\hline & & \multicolumn{7}{|c|}{ Group } \\
\hline & & A & B & $\mathrm{C}$ & $\mathrm{D}$ & $\mathrm{E}$ & $\mathrm{F}$ & G \\
\hline 1 & less than 3 & 285,01 & 311,69 & 342,36 & 377,08 & 415,42 & 457,40 & 504,74 \\
\hline 2 & from 3 to 6 & 296,30 & 324,73 & 356,82 & 392,39 & 432,98 & 477,22 & 525,46 \\
\hline 3 & from 6 to 9 & 308,08 & 337,37 & 370,76 & 407,78 & 450,15 & 497,06 & 546,69 \\
\hline 4 & from 9 to 12 & 319,33 & 350,02 & 385,64 & 423,08 & 467,34 & 516,93 & 568,80 \\
\hline 5 & from 12 to 15 & 331,07 & 363,07 & 400,07 & 439,37 & 485,35 & 535,87 & 590,49 \\
\hline 6 & from 15 to 18 & 343,23 & 375,75 & 414,93 & 455,17 & 503,40 & 555,27 & 612,11 \\
\hline 7 & from 18 to 21 & 355,42 & 388,78 & 429,41 & 471,81 & 521,46 & 574,19 & 633,74 \\
\hline 8 & from 21 to 24 & 367,63 & 401,44 & 444,31 & 488,48 & 539,00 & 593,61 & 655,88 \\
\hline 9 & from 24 to 27 & 379,80 & 414,93 & 459,20 & 505,20 & 557,06 & 613,46 & 677,99 \\
\hline 10 & from 27 to 30 & 391,98 & 428,51 & 473,61 & 521,87 & 575,12 & 633,35 & 700,06 \\
\hline 11 & over 30 & 404,58 & 441,59 & 488,48 & 538,60 & 593,16 & 653,63 & 723,54 \\
\hline
\end{tabular}

\section{Bibliography}

\section{Legal acts and printed sources}

Act no. 122/1926 Collection of laws and orders on the adjustment of salaries of the clergy of churches and religious communities recognized or admitted by the State.

Act no. 124/1948 Coll. on the nationalization of some inn holder and taproom businesses and accommodation facilities.

Act no. 125/1948 Coll. on the nationalization of natural resources and medicinal spas and integration and management confiscated spa property.

Act no. 142/1947 Coll. on the revision of the first land reform.

Act no. 169/1949 Coll. on military districts.

Act no. 176/1898 Coll.

Act no. 217/1949 Coll. on state supervision over the churches.

Act no. 218/1949 Coll. on the financial provision of churches and religious communities by the state.

Act no. 311/2001 Coll. Labour Code as amended.

Act no. 46/1948 Coll. on the so-called new land reform.

Act no. 47/1885 Coll.

Act no. 51/1874 Coll. on contributions to the religious fund.

Act no. 663/2007 Coll. on the minimum wage as amended. 
Act no. 85/1948 Coll. on the nationalization of medical and nursing institutions and the institutional organisation of state medical care.

Act no. 95/1948 Coll. on basic provisions for uniform education (the Education Act).

Code of Canon Law

Government regulation no. 124/1928 Collection of laws and orders on the salary adjustment of the clergy.

Government regulation no. 219/1949 Coll. on the financial provision of the Roman Catholic Church by the state.

Government regulation no. 220/1949 Coll. on the financial provision of the Czechoslovak Church by the state.

Government regulation no. 221/1949 Coll. on the financial provision of the Protestant Churches by the state.

Government regulation no. 222/1949 Coll. on the financial provision of the Orthodox Church by the state.

Government regulation no. 223/1949 Coll. on the financial provision of religious communities by the state.

Government regulation no. 299/2007 Coll. on the treatment of personal emoluments provided for clergymen of churches and religious communities, as amended.

Government regulation no. 70/1968 Coll. on the financial provision of the Greek Catholic Church by the state.

Legal article LXX/1723.

Legal article LXXIV/1715.

Statutory article XIII/1909.

Statutory article XIV/1898.

Statutory article XLII/1895.

Statutory article XXXV/1912.

Statutory article XXXVIII/1913.

\section{Monographs}

Barancová H., Slovenské a európske pracovné právo, Žilina 2004.

Barancová H., Schronk R., Pracovné právo, Bratislava 2013.

Bartal A., Glossarium mediae et infimae latinitatis regni Hungariae, Lipsiae-Budapestini, 1901.

Cikeš R., Financovanie cirkví a náboženských spoločností štátom [in:] Clara pacta-boni amici. Zmluvné vzt'ahy medzi štátom a cirkvami, eds. M. Šmid, M. Moravčíková, Bratislava 2009.

Hrdina I.A., Pracovněprávní poměry duchovních a Zákonník práce, "Právník" 2007, iss. 8.

Kušnyráková I., Piae fundationes. Zbožné fundácie a ich význam pre rozvoj uhorskej spoločnosti v ranom novoveku, Bratislava 2009.

Laclaviková M., Formovanie pracovného práva a práva sociálneho zabezpečenia na našom územi začiatkom 20. storočia [in:] Právnohistorická realita sociálnej doktríny 20. storočia, Kraków 2013.

Malý K., Sivák F., Dejiny štátu a práva v Československu do roku 1918, Bratislava 1992.

Moravčíková M., Cipár M., Cisárovo cisárovi. Ekonomické zabezpečenie cirkví a náboženských spoločností, Bratislava 2001.

Moravčíková M., Štát a cirkev v Slovenskej republike [in:] Štát a cirkev v postsocialistickej Európe, ed. S. Jozefčiaková, Bratislava 2003.

Munka J., Patronátne bremená a cirkevné dávky, Dunajská Streda 1937.

Olšovská A., Pracovnoprávne postavenie osôb vykonávajúcich duchovenskú činnost', “Acta Universitatis Tyrnaviensis", Trnava 2005. 
Pešek J., Barnovský M., Štátna moc a cirkvi na Slovensku 1948-1953, Bratislava 1997.

Slovník verejného práva československého. Svazek II., eds. E. Hácha, J. Hoetzel, F. Weyr, K. Laštovka, Brno 1932.

Šabo M., Štát a cirkvi na Slovensku. Vývoj financovania cirkví, Bratislava 2006.

Šabo M., Model financovania Katolíckej cirkvi v Slovenskej republike v kontexte vývoja, princípov a perspektív vzt'ahov štátu a cirkví vo svete, Bratislava 2008.

Tóth L., Postavenie zamestnancov cirkvi a náboženských spoločností [in:] Teoretické úvahy o práve, Trnava 2011.

Tretera J.R., Stát a cirkve v České republice, Kostelní Vydř́ 2002.

Tretera J.R., Horák Z., Konfesní právo, Praha 2016.

Valeš V., Právni úprava postavení církví a náboženských společností v období prvni Československé republiky (1918-1938), Praha 2013.

Vaško V., Neumlčená. Kronika katolické cirkve v Československu po druhé světové válce, Praha 1996.

Žofčinová V., Gyuri R., Osobitosti v pracovnoprávnom postavení zamestnancov cirkví a náboženských spoločností [in:] Sloboda jednotlivca a svet práce, eds. V. Križan, M. Moravčková, Praha 2014. 